\title{
Diversity of Medicinal Plants among Different Forest-use Types of the Pakistani Himalaya ${ }^{1}$
}

\author{
Muhammad Adnan $^{*, 2,3}$ AND Dirk HÖlscher ${ }^{2}$ \\ ${ }^{2}$ Tropical Silviculture and Forest Ecology, Burckhardt Institute, Georg-August-Universität Göttingen, \\ Büsgenweg 1, 37077 Göttingen, Germany \\ ${ }^{3}$ Department of Botany, Kohat University of Science and Technology, 26000 Kohat, Khyber \\ Pakhtunkhwa, Pakistan \\ *Corresponding author; e-mail: madnan@gwdg.de, ghurzang@hotmail.com
}

\begin{abstract}
Diversity of Medicinal Plants among Different Forest-use Types of the Pakistani Himalaya
Medicinal plants collected in Himalayan forests play a vital role in the livelihoods of regional rural societies and are also increasingly recognized at the international level. However, these forests are being heavily transformed by logging. Here we ask how forest transformation influences the diversity and composition of medicinal plants in northwestern Pakistan, where we studied old-growth forests, forests degraded by logging, and regrowth forests. First, an approximate map indicating these forest types was established and then 15 study plots per forest type were randomly selected. We found a total of 59 medicinal plant species consisting of herbs and ferns, most of which occurred in the old-growth forest. Species number was lowest in forest degraded by logging and intermediate in regrowth forest. The most valuable economic species, including six Himalayan endemics, occurred almost exclusively in oldgrowth forest. Species composition and abundance of forest degraded by logging differed markedly from that of old-growth forest, while regrowth forest was more similar to oldgrowth forest. The density of medicinal plants positively correlated with tree canopy cover in old-growth forest and negatively in degraded forest, which indicates that species adapted to open conditions dominate in logged forest. Thus, old-growth forests are important as refuge for vulnerable endemics. Forest degraded by logging has the lowest diversity of relatively common medicinal plants. Forest regrowth may foster the reappearance of certain medicinal species valuable to local livelihoods and as such promote acceptance of forest expansion and medicinal plants conservation in the region.
\end{abstract}

Key Words: Forest degradation, forest recovery, livelihood, similarity, non-timber forest products.

\section{Introduction}

Medicinal plants can provide a significant source of income for rural people in developing countries, especially through the sale of wild harvested material, which contributes $15-30 \%$ to the total income of poorer households (Hamilton 2004). The importance of medicinal plants is increasingly being recognized in the Himalayan region (Larsen et al. 2000; Olsen 2005) and particularly from ecological, social, and economic perspectives (Arnold and Pérez 2001; Negi et al. 2011). Despite their significance to rural livelihoods, the

\footnotetext{
${ }^{1}$ Received 1 November 2011; accepted 19 September 2012; published online 14 December 2012
}

abundance and diversity of understory medicinal plant species are threatened by changes in the structural attributes of the overstory in native oldgrowth forest as a result of degradation (Gilliam 2007; Liira et al. 2007; Ticktin et al. 2007; Wyatt and Silman 2010). Changes in the structure of Himalayan forests have been reported in many studies (Kumar and Ram 2005; Nath et al. 2005; Schickhoff 1995), with most being attributed to anthropogenic activities. For example, degradation in Himalayan forests has caused rapid declines in both diversity and abundance of understory species (Mishra et al. 2004). On the other hand, in other regions of the world, it has been reported that where degraded forest are allowed to regrow, the probability of recurrence of understory species that 
had previously disappeared is greater (Barbier et al. 2008; Parrotta et al. 1997). However, such studies are scarce from Himalayan forests, so the evaluation of the extent to which forest degradation and subsequent forest regrowth brings about changes in the diversity of understory flora has not been possible.

In the mountainous region of Pakistan, local people collect around 600 medicinal plant species (approximately $10 \%$ of the total reported plant species) to support their livelihoods (Shinwari 2010). Most of these species are understory herbs and ferns. Pakistan, with a forest cover of $4.8 \%$ (Lubna 2001) is undergoing severe deforestation at a rate of $1.5 \%$ per year (FAO 2005). At this rate, the current forest cover of the country may have already been reduced to approximately $4.3 \%$, with associated negative effects on the associated ground flora. Another possible consequence of deforestation in Pakistan is the disastrous flood of 2010, particularly in the northwest region (Rodriguez 2010), where our study was conducted. Thus, it is widely accepted that there is a need for the expansion of forest area both to enhance livelihoods of local populations and to contribute toward flood prevention measures.

The objectives of our study were 1) to compare the diversity of medicinal plants among various forest-use types, and 2) to assess the relationship between forest tree structural variables and diversity of medicinal plants. These objectives were selected with a view toward informing potential conservation and regeneration measures for medicinal plant species in Pakistan.

\section{Materials and Methods}

\section{STUdy AREA}

The study was carried out in the Khyber Pakhtunkhwa (KPK) province, the former Northwest Frontier Province of Pakistan, which constitutes $40 \%$ of the country's forested area (Lubna 2001). Forests cover $17 \%$ of the province (WWF-P 2004) and stretch across the Himalayas, Hindu Kush, and Karakurum mountain ranges. Covering an area of 3,312 ha, the Ayubia National Park (ANP) is one of 24 national parks in Pakistan and is situated between 330-01' and $34^{\circ}-38^{\prime} \mathrm{N}$ latitude and $73^{\circ}-20^{\prime}$ and $73^{\circ}-30^{\prime} \mathrm{E}$ longitude (Fig. 1b). The study covered the ANP and its surrounding forests, which together constitute 8,978 ha in area. The study area ranged from $1,220 \mathrm{~m}$ to $2,865 \mathrm{~m}$ in altitude and lies within reach of the monsoon, resulting in a mean annual precipitation of $1,500 \mathrm{~mm}$. There is snow cover between November and March and the mean annual temperature is $12{ }^{\circ} \mathrm{C}$ (WWF-P 2004). The natural vegetation in the study area is Himalayan moist forest. The dominant tree species are Abies pindrow Royle, Cedrus deodara G. Don, Pinus roxburghii Sargent, Pinus wallichiana A.B. Jacks, Quercus incana Roxb, and Taxus wallichiana Zacc (Shafiq 2003).

Approximately 50,000 people currently live in twelve villages around the ANP. Fuelwood consumption of each household in the study area has been estimated at 11,000 kg/year dry weight (Aumeeruddy et al. 2004; Hussain 2003). Annually, 13 tons of fresh fodder (grasses and herbaceous species) are collected per household, of which $34 \%$ are medicinal plants (Rabia and Khan 2004). The collection of fuelwood and fodder are mostly the responsibility of women. In a region similar to the study area, around $47 \%$ of children are involved in the collection, $55 \%$ of women in processing, and $70 \%$ of men in the marketing of medicinal plants. About $10 \%$ of the local population is employed full-time in the collection and marketing of plants with approximately $30 \%$ being employed part-time (Ahmad 2003). Thus these extractive activities represent locally important economic activities in the region.

\section{Forest Administration History, Forest-use Types, and Plot Selection}

The administration and management approach of the forests dates back to 1857 following British colonization, when they were designated as "reserved" forests and "Guzara" forests. Reserved forests are defined as forests in which all human disturbance is prohibited, whereas Guzara forests are intended to meet domestic requirements (forest products) of local people. A part of the reserved forest was declared a national park in 1984 (Ayubia National Park, ANP), and the management was handed over to the KPK wildlife department. Guzara forests and reserve forests outside the ANP are administered by the KPK forest department (Farooque 2002).

For the present study we selected three forestuse types: old-growth forest, forest degraded by logging, and regrowth forest. Old-growth forest refers to forest with little or no human disturbance, and is characterized by an abundance of 


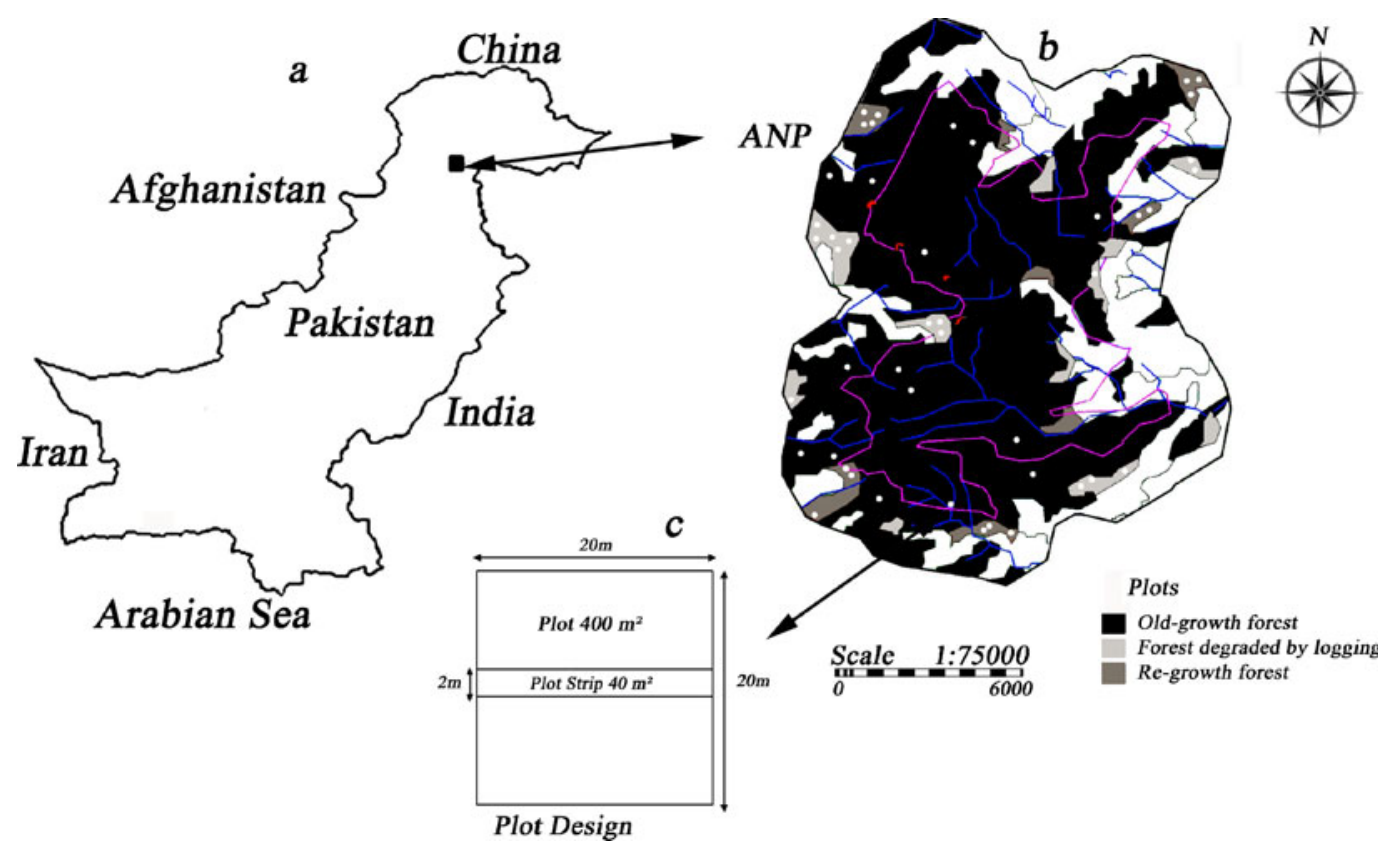

Fig. 1. Map of the study area, forest-use types and plot design. (a) Pakistan and the location of the study region. (b) The study region with the Ayubia National Park (ANP) boundary, its surrounding forests (outside boundary), and randomly selected study plots in all forest use types (dots). (c) Plot design; includes inventory plot for trees $\left(400 \mathrm{~m}^{2}\right)$ and plot strip for medicinal plants $\left(40 \mathrm{~m}^{2}\right)$. The white area in $1 \mathrm{~b}$ shows derived woodland and agroforest (Adnan and Hölscher 2011), both of which are not included in this study.

large diameter trees and a mainly closed forest canopy. Old-growth forest can mainly be found in the ANP and in surrounding reserve forests and should consequently be afforded the highest level of protection from resource exploitation.

Forests degraded by logging are considerably affected by selective tree felling; many stumps of timber species such as Cedrus deodara and Pinus wallichiana and preferred fuelwood species such as Quercus spp. can be found. They occur in both reserve and Guzara forests and have a relatively open canopy. In addition, this forest-use type also supported livestock grazing, fodder collection, and the gathering of valuable medicinal plants species before the introduction of protection measures, which have restricted such anthropogenic activities since 2008 with the support of the community and World Wide Fund for Nature Pakistan.

Regrowth forests are areas naturally regenerating after heavy logging (for domestic and commercial purposes) of old-growth forests. They consist mainly of narrow-diameter trees with a high stem density. They generally occur within reserve forests and the ANP. The existence of some remnant trees identifies these forest-use types as regrowth forests, as opposed to secondary forest identified in a study by Putz and Redford (2010). Such forests have been free from logging and other anthropogenic activities for approximately 50 years, and, like oldgrowth forest, this forest-use type is also afforded some statutory protection.

In addition to the above forest-use types, there are some agroforests and derived woodlands in the Guzara forests (Adnan and Hölscher 2011) from which local communities living around the ANP meet most of their requirement for fodder, fuelwood, and medicinal plants. Despite statutory protection, some human interference for the collection of such forest resources was observed in certain parts of the ANP and reserve forests (Aumeeruddy et al. 2004). This is due to their proximity to the community, complexities in the land tenure laws, and the actual status of what is supposed to be Guzara forest, reserved forests, or the ANP, which is sometimes unclear to local people.

Data for the study were developed in three stages. First, from July to October 2008, a reconnaissance survey was conducted for the identification of selected forest-use types and the development of a GIS based map (Fig. 1b). 
Fifteen study plots were randomly selected within a sample area of 1,406 ha within each forest-use type and within an altitudinal range of between 2,200 and 2,400 masl. Random sample points were selected using the ILWIS software (Version 3.4: ITC 2007) which generates random values, one for the $\mathrm{X}$ axis and one for the $\mathrm{Y}$ axis, with the point of intersection representing the sample point. Each random point represented the center of each sample plot. Next, field data on forest structure were collected from the selected plots between June and September 2009. This was followed by a brief survey of the diversity of medicinal plants between August and September 2010.

\section{Medicinal Plants and Uses}

Medicinal plants include plants that are traditionally used for the treatment of various human diseases and in ethnoveterinary medicine (EVM). Species identification in the field was facilitated by local collectors of medicinal plants and by a taxonomist from the World Wide Fund for Nature Pakistan (WWF-P). Plant samples were collected from the field, and herbarium vouchers were stored at WWFPakistan's Nathiagali office. All medicinal plant vouchers were corrected for their botanical names, family names, and publication authors according to the software Index Kewensis version 2.0 (1997). From the available literature and collector information, local names and uses were documented (Shafiq 2003; Sher and Khan 2006), along with reproductive strategies and light requirements [Refer to Appendix in Electronic Supplementary Material (ESM)] (Fern 1997).

Most local names of medicinal plants were recorded in two languages: Hindko (spoken in the study area) and Pashto (spoken in most parts of northwest Pakistan). Medicinal plants are used whole or in parts-leaves, whole roots or tubers, stems, flowers and seeds, or fruits. Almost all medicinal plant species also have a secondary use such as fodder, vegetables, insecticides, fruits, narcotics, cosmetics, handicrafts, dyes, tea, and others. Medicinally, these plants are used to treat a number of conditions ranging from fever to cardiac problems [Refer to Appendix in Electronic Supplementary Material (ESM)] (Gillani et al. 2010; Ibrar 2003).

\section{Forest Tree InVEntory and Medicinal Plants AsSESSMENT}

Plot design consisted of tree inventory plots of $20 \times 20 \mathrm{~m}\left(400 \mathrm{~m}^{2}\right)$ for data collection of the stand structural variables (Table 1 ). Within each inventory plot, a sample plot strip of $20 \times 2 \mathrm{~m}$ $\left(40 \mathrm{~m}^{2}\right)$ (Fig. 1c) was subdivided into 10 quadrates of $4 \mathrm{~m}^{2}$, and plant density, species richness, and species frequency of medicinal plants were recorded therein. The density of each plant species was recorded by counting the number of individuals; the frequency of each medicinal plant was recorded as the percentage of plots that included the species. The estimations of density and frequency of medicinals were carried out following the protocol outlined by Curtis and McIntosh (1951). Species richness, ShannonWiener diversity index $\mathrm{H}^{\prime}$, and Shannon evenness of medicinal plants (Magurran 2004) per plot strip were calculated. The Jaccard abundancebased similarity index (Chao et al. 2005) and the Sørensen similarity index based on species presence-absence (Magurran 2004) were applied to quantify medicinal species turnover within forestuse types. The Jaccard index was also applied to quantify similarity of given forest-use type with old-growth forest on the basis of medicinal plant abundance. Higher values of these indices correspond to a higher similarity in species composition, lower beta diversity, and lower species turnover (Chao et al. 2005).

Indicator species analysis (Dufrêne and Legendre 1997) was used to calculate indicator values for each medicinal plant species in each forest-use type as the product of the species' mean abundance in a particular forest-use type relative to other forest-use types and the proportion of plots in that forest-use type where it was present. The indicator values represent the degree to which species vary among forest-use types in both relative frequency and relative abundance. The prices of medicinal plant species were taken from the local market in Abbottabad city in 2010.

\section{Statistical Analysis}

The Mann-Whitney test was applied to test differences in the mean values of medicinal plant variables among given forest-use types. For a given forest-use type, a Spearman correlation was performed between tree stand structural variables and medicinal plant variables. Across forest-use types, a detrended correspondence analysis (DCA) was used to identify the variables of forest tree stand structure most probably related to the densities of medicinal plants and to differentiate 
Table 1. GENERAL ATTRIBUTES AND TREE STAND STRUCTURAL CHARACTERISTICS OF THREE FOREST-USE TYPES. MEAN AND STANDARD ERROR, N=15 PLOTS PER FOREST-USE TYPE. DIFFERING SMALL LETTERS INDICATE STATISTICAL DIFFERENCES $(\mathrm{P} \leq 0.05)$ IN THE MANN-WHITNEY TEST.

\begin{tabular}{|c|c|c|c|}
\hline & $\begin{array}{l}\text { Old-growth forest } \\
\text { Mean } \pm \text { SE }\end{array}$ & $\begin{array}{c}\text { Forest degraded by logging } \\
\text { Mean } \pm \text { SE }\end{array}$ & $\begin{array}{c}\text { Regrowth forest } \\
\text { Mean } \pm \text { SE }\end{array}$ \\
\hline Study area (ha) within $2200-2400 \mathrm{~m}$ asl & 915 & 279 & 212 \\
\hline Altitude of study plots (masl) & $2373 \pm 20$ & $2350 \pm 34$ & $2293 \pm 40$ \\
\hline Distance from the nearest community $(\mathrm{km})$ & $3.2 \pm 0.5$ & $1.0 \pm 0.2$ & $1.7 \pm 0.2$ \\
\hline Slope $(\%)$ & $35 \pm 2.6$ & $18 \pm 2.7$ & $26 \pm 2.8$ \\
\hline Northern aspect (\%) & 40 & 47 & 60 \\
\hline Total number of tree species $(\geq 10 \mathrm{~cm} \mathrm{dbh})$ & 15 & 6 & 12 \\
\hline Stem density $(\geq 10 \mathrm{~cm}$ dbh $)\left(\mathrm{n} \mathrm{ha}^{-1}\right)$ & $610 \pm 34 \mathrm{~b}$ & $183 \pm 29 \mathrm{c}$ & $750 \pm 53$ a \\
\hline Basal area $\left(\mathrm{m}^{2} \mathrm{ha}^{-1}\right)$ & $48 \pm 2$ a & $12 \pm 1 \mathrm{c}$ & $20 \pm 1 \mathrm{~b}$ \\
\hline Tree canopy cover $(\%)$ & $76 \pm 4 \mathrm{a}$ & $46 \pm 3 c$ & $56 \pm 4 \mathrm{~b}$ \\
\hline Tree species richness (no per $400 \mathrm{~m}^{2}$ ) & $3.1 \pm 0.3 \mathrm{a}$ & $1.9 \pm 0.2 \mathrm{~b}$ & $2.9 \pm 0.4 \mathrm{a}$ \\
\hline Leaf area index (LAI) & $4.7 \pm 0.4 \mathrm{a}$ & $1.8 \pm 0.3 \mathrm{c}$ & $3.0 \pm 0.2 \mathrm{~b}$ \\
\hline Shannon index, trees $\left(\mathrm{H}^{\prime}\right)$ & $0.94 \pm 0.1 \mathrm{a}$ & $0.49 \pm 0.1 \mathrm{~b}$ & $0.74 \pm 0.1 \mathrm{ab}$ \\
\hline Litter thickness (cm) & $3.4 \pm 0.4 \mathrm{a}$ & $1.3 \pm 0.2 \mathrm{c}$ & $2.1 \pm 0.2 \mathrm{~b}$ \\
\hline Litter cover (\%) & $89 \pm 2$ a & $44 \pm 5 c$ & $74 \pm 3 b$ \\
\hline
\end{tabular}

medicinal plant species in relation to their correlation with the axes. Thus, nine forest treestand structural variables (basal area, tree canopy cover, stem density, height, leaf area index, Shannon evenness, Shannon index, litter thickness, litter cover) were standardized to ensure equal weight was attributed to each of the variables. Data on the density of medicinal plants were logarithmically transformed as DCA based on the assumption of normally distributed data.

Indicator values of medicinal plant species among forest-use types were tested for statistical significance using a Monte Carlo test at 1,000 permutations; significance was indicated by “*”. DCA and Monte Carlo tests were carried out using PC-ORD (Version 5.06) (McCune and Mefford 1999). Data compilation, MannWhitney tests, Jaccard abundance index, Sørensen similarity index, and Spearman correlation were carried out using Microsoft Excel and SPSS (Version 16.0) (SPSS Inc. 2007).

\section{Results}

Comparison of Medicinal Plants' Diversity and Abundance as a Whole BETWEEN FOREST-USE TYPES

A total number of 59 medicinal plant species (herbs and ferns) occurred on the study plots, of which 41 were perennial, thirteen were annual, and five were biennial. Twenty-nine species were used for their leaves and 20 species for their roots and tubers. In addition to medicinal uses, 24 plants were used as fodder and eleven as vegetables. Most of the medicinal plant species (28) were used to treat various intestinal diseases, followed by 21 for stomach diseases [Refer to Appendix in Electronic Supplementary Material (ESM)].

The highest number of the medicinal plant species (55) occurred in old-growth forest, 40 species grew in forest degraded by logging, and 49 species grew under regrowth forest. The mean species richness of medicinal plants (18.1 per $40 \mathrm{~m}^{2}$ plot) in old-growth forest plots was almost two times higher than in forest degraded by logging (Table 2). For medicinal plants, presencel absence in old-growth forest was observed with significantly higher Sørensen similarity index within the plots $(0.42)$ in comparison to forest degraded by logging (0.29). For medicinal plant abundance, a significantly higher Jaccard similarity index with old-growth forest was recorded for regrowth forest $(0.34)$ than for forest degraded by logging (0.20) (Fig. 2).

The mean density of all medicinal plants $\left(20 \mathrm{~m}^{-2}\right)$ in regrowth forest plots was greater than that in forest degraded by logging $\left(13.7 \mathrm{~m}^{-2}\right)$. Similarly, the mean Shannon diversity index $\mathrm{H}^{\prime}$ for regrowth forest (2.3) was also significantly higher than forest degraded by logging (1.8). The mean Shannon evenness of medicinal plants 
Table 2. OVERALL DIVERSITY AND DENSITY OF MEDICINAL PLANTS IN OLD-GROWTH FOREST, FOREST DEGRADED BY LOGGING, AND REGROWTH FOREST. MEAN AND STANDARD ERROR, N=15 PLOTS PER FOREST-USE TYPE. DIFFERING SMALL LETTERS INDICATE STATISTICAL DIFFERENCES $(\mathrm{P} \leq 0.05)$ IN THE MANN-WHITNEY TEST.

\begin{tabular}{llll}
\hline \hline & $\begin{array}{c}\text { Old-growth forest } \\
\text { Mean } \pm \mathrm{SE}\end{array}$ & $\begin{array}{c}\text { Forest degraded by logging } \\
\text { Mean } \pm \mathrm{SE}\end{array}$ & $\begin{array}{c}\text { Regrowth forest } \\
\text { Mean } \pm \mathrm{SE}\end{array}$ \\
\hline Total number of species & 55 & 40 & 49 \\
Density (n per $\mathrm{m}^{-2}$ ) & $19.1 \pm 1.8 \mathrm{a}$ & $13.7 \pm 2.6 \mathrm{~b}$ & $20.0 \pm 3.1 \mathrm{a}$ \\
Species richness $\left(\mathrm{n}\right.$ per $40 \mathrm{~m}^{2}$ plot $)$ & $18.1 \pm 1.4 \mathrm{a}$ & $10.1 \pm 1.0 \mathrm{~b}$ & $15.3 \pm 1.4 \mathrm{a}$ \\
Shannon index $\left(\mathrm{H}^{\prime}\right)$ & $2.2 \pm 0.1 \mathrm{ab}$ & $1.8 \pm 0.2 \mathrm{~b}$ & $2.3 \pm 0.1 \mathrm{a}$ \\
Shannon Evenness $\left(\mathrm{E}_{\mathrm{H}}\right)$ & $0.77 \pm 0.02 \mathrm{~b}$ & $0.80 \pm 0.06 \mathrm{a}$ & $0.84 \pm 0.02 \mathrm{a}$ \\
Sørensen index & $0.42 \pm 0.03 \mathrm{a}$ & $0.29 \pm 0.03 \mathrm{c}$ & $0.38 \pm 0.03 \mathrm{~b}$ \\
Chao abundance based index & $0.48 \pm 0.04 \mathrm{a}$ & $0.24 \pm 0.03 \mathrm{c}$ & $0.32 \pm 0.04 \mathrm{~b}$ \\
\hline
\end{tabular}

under both regrowth forest (0.84) and forest degraded by logging $(0.80)$ was significantly higher than in old-growth forest (0.77). Oldgrowth forest and regrowth forest showed no significant differences for mean species' density, richness, or Shannon diversity index $\mathrm{H}^{\prime}$ (Table 2).

Twenty medicinal species were identified as significant indicator species for given forest types. Fourteen were indicator species of old-growth forest, including species endemic to the Himalayan region such as Aconitum heterophyllum, Arum venosum, Coptis tecta, Impatiens bicolor, Paenonia emodi, and Podophyllum emodi. Four species were indicator species of regrowth forest, and only two were indicator species of forest degraded by logging. The local market prices of these medicinal plant species ranged between 0.2 and $9.0 \mathrm{USD} \mathrm{kg}^{-1}$ (Table 3).

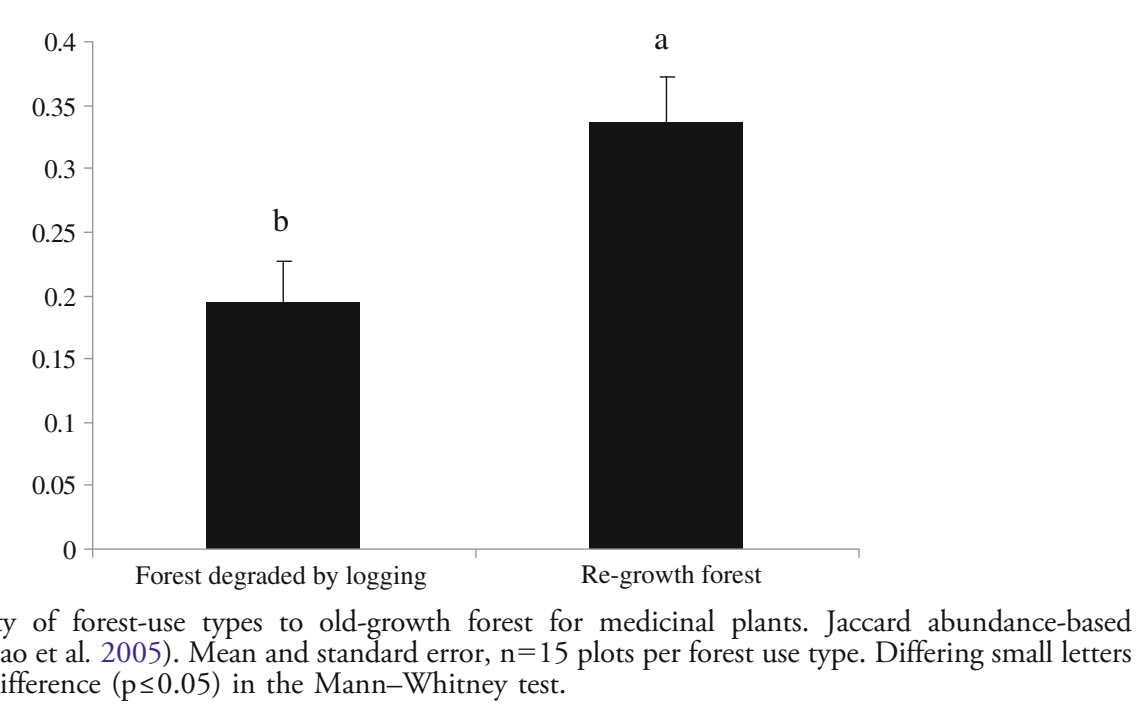

Fig. 2. Similarity of forest-use types to old-growth forest for medicinal plants. Jaccard abundance-based similarity index (Chao et al. 2005). Mean and standard error, $n=15$ plots per forest use type. Differing small letters indicate statistical difference $(\mathrm{p} \leq 0.05)$ in the Mann-Whitney test.

\section{Relationships between Tree Stand Structure and Medicinal Plants}

Tree canopy cover in old-growth forest showed a significantly positive correlation with density of medicinal plants $(\mathrm{r}=0.69, \mathrm{n}=15, \mathrm{p}<0.01)$. However, tree canopy cover was significantly negatively correlated with Shannon evenness of medicinal plants under old-growth forest $(\mathrm{r}=-0.58$, $\mathrm{p}<0.05)$. In contrast, tree canopy cover under forest degraded by logging showed a significantly negative correlation with density of medicinal plants $(\mathrm{r}=$ $-0.87, \mathrm{p}<0.01$ ). The Shannon $\mathrm{H}^{\backslash}$ of trees showed a significantly positive correlation with Shannon $\mathrm{H}^{\prime}$ of all medicinal plants under each forest-use type (Table 4).

As indicated by the DCA on the 45 plots of three forest-use types, the axis-1 (eigenvalue = 0.36) of forest stand structural data correlated 
Table 3. SPECIES INDICATOR VALUES OF MEDICINAL PLANT SPECIES UNDER EACH FOREST-USE TYPE. “*” INDICATES SIGNIFICANCE OF OBSERVED MAXIMUM INDICATOR VALUE FOR SPECIES (MONTE CARLO TEST AT 1,000 PERMUTATIONS). “"” INDICATES NOT AVAILABLE. MARKET PRICES ARE AS PER LOCAL MARKET RATE. DISTRIBUTION; VULNERABILITY (ALI 2011; FERN 1997; WWF-P 2004).

\begin{tabular}{|c|c|c|c|c|c|}
\hline \multirow[b]{2}{*}{ Botanical name } & \multirow[b]{2}{*}{$\begin{array}{l}\text { Market price } \\
\left(\mathrm{USD} \mathrm{Kg}^{-1}\right)\end{array}$} & \multicolumn{3}{|c|}{ Indicator values (\%) } & \multirow[t]{2}{*}{ "Distribution; vulnerability } \\
\hline & & $\begin{array}{l}\text { Old-growth } \\
\text { forest }\end{array}$ & $\begin{array}{l}\text { Forest degraded } \\
\text { by logging }\end{array}$ & $\begin{array}{l}\text { Regrowth } \\
\text { forest }\end{array}$ & \\
\hline Aconitum heterophyllum & 7,0 & $60^{*}$ & - & - & Himalayas; highly vulnerable \\
\hline Adiantum capillus-veneris & 1.5 & $33^{*}$ & - & - & Himalayas; highly vulnerable \\
\hline Ajuga bracteosa & 3,0 & $33^{*}$ & - & - & Himalayas, Malaysia \\
\hline Arum venosum & 1 & $33^{*}$ & - & - & Himalayas \\
\hline Atropa acuminata & 2 & $33^{*}$ & - & - & $\begin{array}{l}\text { Himalayas, Iran; highly } \\
\text { vulnerable }\end{array}$ \\
\hline Bergenia ciliata & 2,5 & $38^{*}$ & - & 5 & $\begin{array}{l}\text { East Asia, Himalayas; highly } \\
\text { vulnerable }\end{array}$ \\
\hline Coptis tecta & 2 & $27^{*}$ & - & - & Himalayas \\
\hline Dryopteris ramosa & 1 & $31^{*}$ & - & 14 & - \\
\hline Foeniculum vulgare & 3,0 & 1 & 3 & $30^{*}$ & - \\
\hline Fragaria nubicola & 0,5 & 2 & $39^{*}$ & 8 & - \\
\hline Geranium wallichianum & 2 & 24 & 3 & $46^{*}$ & - \\
\hline Impatiens bicolor & 3,5 & $53^{*}$ & - & - & Himalayas \\
\hline Paeonia emodi & 2,3 & $24^{*}$ & - & 1 & Himalayas; highly vulnerable \\
\hline Podophyllum emodi & 4,5 & $49^{*}$ & - & 4 & Himalayas; highly vulnerable \\
\hline Silybum marianum & 0.5 & - & 10 & $33^{*}$ & $\begin{array}{l}\text { Himalayas, west Asia, South } \\
\text { Europe, North Africa }\end{array}$ \\
\hline Trifolium repens & 0.2 & 1 & $38^{*}$ & 1 & - \\
\hline Urtica dioica & 1,5 & $33^{*}$ & - & - & $\begin{array}{l}\text { Himalayas, temperate regions } \\
\text { of both hemispheres }\end{array}$ \\
\hline Valeriana jatamansi & 6,0 & $67^{*}$ & 1 & 16 & - \\
\hline Veronica laxa & 1 & 3 & - & $31^{*}$ & Himalayas, Japan \\
\hline Viola canescens & 9,0 & $70^{*}$ & 1 & 18 & - \\
\hline
\end{tabular}

with tree canopy cover $(\mathrm{r}=0.76, \mathrm{p}<0.01)$. The density of 18 species showed positive correlations with axis-1, such as Valeriana jatamansi and Viola canescens, indicating that the densities of these medicinal plants increases with increasing tree canopy cover. The densities of eight medicinal plants showed negative correlations with axis-1, such as Chrysanthemum leucanthemum, Galium

Table 4. SPEARMAN CORRELATION BETWEEN MEDICINAL PLANT VARIABLES AND TREE STAND STRUCTURAL VARIABLES UNDER EACH FOREST-USE TYPE ( $=15)$; “*” INDICATES SIGNIFICANT CORRELATION AT P $\leq 0.05$ AND “**” INDICATES HIGHER SIGNIFICANT CORRELATION AT P $\leq 0.01$. NS $=$ NO SIGNIFICANT CORRELATION.

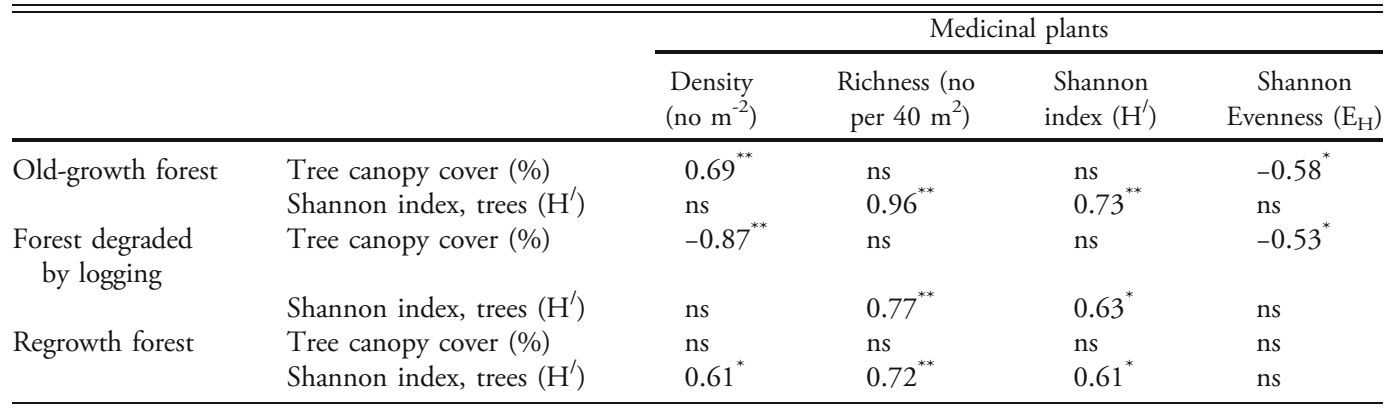


aparine, and Trifolium repens, which implies that these species decrease with increasing tree canopy cover. The densities of 33 medicinal plants did not show any correlation with axis-1, such as Achillea millefolium, Agrimonia eupatoria and Gentiana kurroo, and they were canopy-cover indifferent species (Fig. 3).

\section{Discussion}

Multi-use medicinal plants are an important part of the understory flora and play an essential role both socioeconomically and ecologically in the region. The present study indicates variation in the diversity of understory medicinal plant species among studied forest-use types. In particular, oldgrowth forests had a higher diversity of medicinal plants compared to forests degraded by logging. Species density, species richness, Shannon diversity, and similarity of medicinal plants were also higher in old-growth forest than in forest degraded by logging. A higher density of medicinal plants was found in relation to higher tree canopy cover, while a higher diversity of medicinal plants was related to higher tree diversity in old-growth forest. These findings support other studies on Himalayan forests that indicate a higher diversity and abundance of understory plant species in undisturbed compared to disturbed native forest (Bhuyan et al. 2003; Sundriyal and Sharma 1996; Uniyal et al. 2010). The effect of a more open canopy may explain the lower values of medicinal plant variables under forest degraded by logging in comparison to oldgrowth forest. Disturbed overstory has been proposed as one of the reasons for declines in diversity of plant species in the Khasi hills of Meghalaya, India (Mishra et al. 2004).

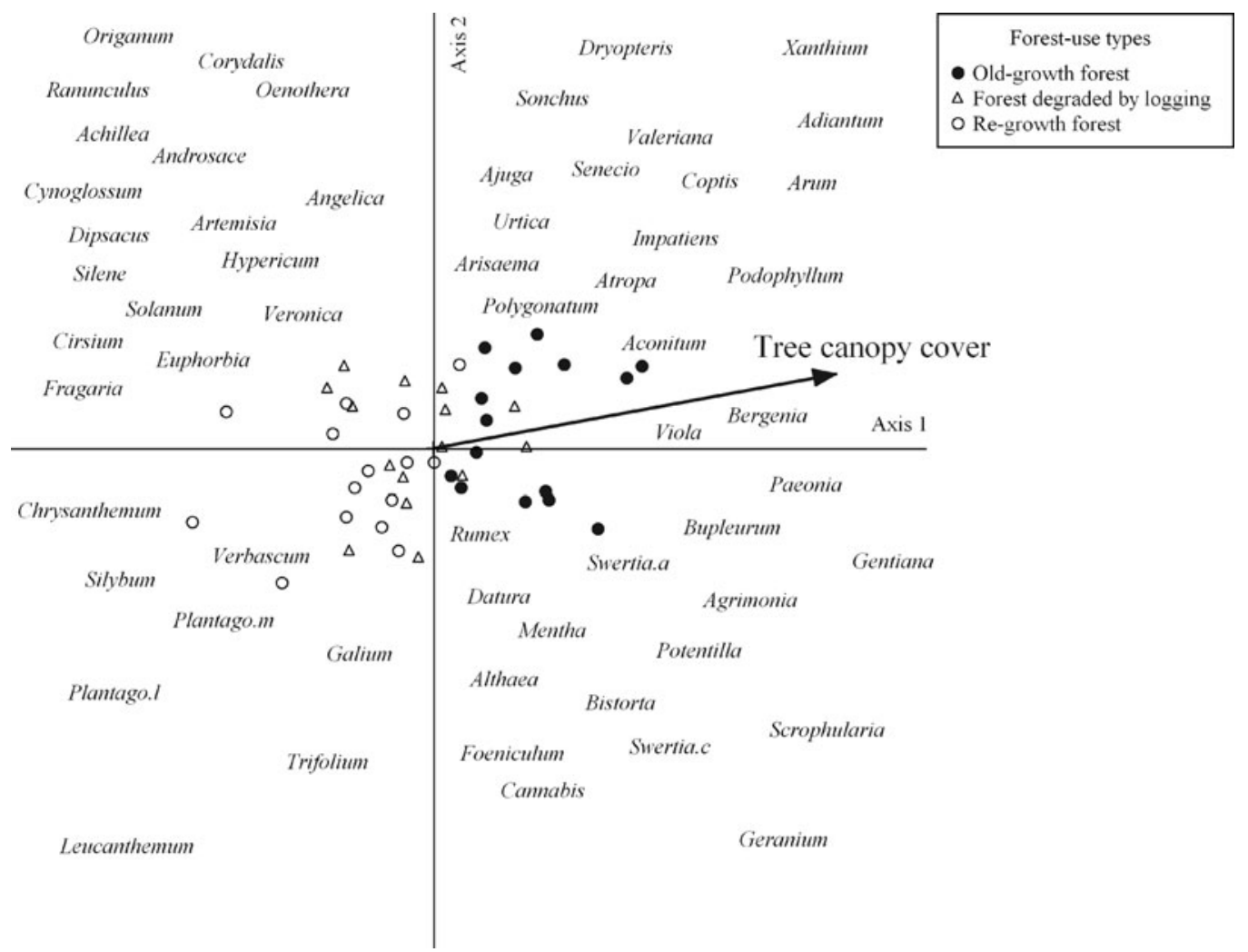

Fig. 3. Detrended correspondence analysis (DCA) for the response of medicinal plant species densities to tree canopy cover in three forest-use types. Matrix consisted of 45 plots, 59 medicinal plants and tree canopy cover. Axis 1: eigenvalue $=0.36$, explained variance $=31 \%$; Correlation threshold $r^{2}>0.55$; Angle $=-20$ degrees; Vector scaling $=121$. Strong significant correlations (Spearman) at $\mathrm{p}<0.01$ have been observed for tree canopy cover $(\mathrm{r}=$ 0.76 ) with axis-1. In medicinal plants, 18 species showed positive correlation, eight species negative correlation and 33 showed no correlation with axis-1. Axis 2 provided little information and was therefore not included in the data set. Refer to Appendix in Electronic Supplementary Material (ESM) for complete botanical names of medicinal plants. 
In contrast, some studies showed lower diversity of medicinal species under undisturbed, abundant overstory in comparison to disturbed and more open overstories (Aguilar-Støen and Moe 2007; Nath et al. 2005; Voeks 1996, 2004). However, a comparison of such studies with our study is complicated by variation in a number of prevailing factors between the study areas. In our study, lower tree canopy cover was related to a higher density of medicinal plants under forest degraded by logging, most probably due to the presence of certain species adapted to sunny conditions. In addition, the past land-use history of forest degraded by logging in our study revealed overcollection of medicinal plants that may have been associated with a lower abundance and diversity of medicinal plants.

Regrowth forest was found to have a more diverse medicinal flora than forest degraded by logging. Studies have confirmed that if a forest is allowed to regenerate and is protected, the understory species that had once disappeared from it also regenerate (Islam et al. 2001; Keersmaeker et al. 2011; Parrotta et al. 1997). Forest regrowth alters conditions for the ground vegetation, such as soil fertility, light, temperature, and moisture (Barbier et al. 2008; Carnevale and Montagnini 2002; Shankar et al. 1998), all of which affect competition dynamics at ground level. In our study, higher medicinal plant density and diversity were related to higher tree diversity under forest regrowth. Moreover, regrowth and old-growth forests exhibited only minor differences in medicinal plant density, richness, and diversity. Similar results were found by Harrelson and Matlack (2006) in their study of Mesophytic old and young forest stands in southeastern Ohio, U.S.A., suggesting that regrowth forest supports the recovery of medicinal understory plants to a level similar to that found in old-growth forest when it was protected and allowed to naturally regrow.

Medicinal plants under forest degraded by logging and regrowth forest were more evenly distributed than those under old-growth forest. Low evenness of species under old-growth forest might have resulted from high variations in the densities of medicinal plants that are adapted to various growing conditions. This is evident from the results of this study, wherein higher tree canopy cover resulted in low evenness of medicinal plants under old-growth forest. A study on Quercus leucotrichophora forest in the Garhwal
Himalaya likewise showed lower evenness of herb species under undisturbed forest than under highly-disturbed forest (Uniyal et al. 2010). And D'Amato et al. (2009) found lower herbaceous species evenness under old-growth forest of Tsuga canadensis due to lower species richness when compared to second-growth forest.

Across forest-use types, higher tree canopy cover was associated with the increased abundance of certain medicinal plants. This included the most valuable species such as Aconitum heterophyllum, Podophyllum emodi, Valeriana jatamansi, and Viola canescens, which are also adapted to deep-shade conditions. The density of such medicinal plant species was found to be higher under old-growth forest in comparison to other forest-use types. This influence might be due to the natural effect of crown cover on the amount of available light for ground vegetation (Shanley and Luz 2003). The abundant overstory provides habitat that promotes shade-adapted understory species while suppressing sun-adapted species (Balandier et al. 2006; Sharma et al. 2009).

The old-growth forests harbor many species that are endemic to the Himalayan region. Studies have confirmed that nearly half of the plant population of the Himalayan region is endemic (Kala 2004; Samant and Dhar 1997). For example, Aconitum heterophyllum, an endemic species of the northwestern Himalayas (Kala 2004) that is critically endangered (Beigh et al. 2006), was only encountered in old-growth forest and was absent from forest degraded by logging and regrowth forests. Other species that were only found in old-growth forest, such as Arum venosum, Coptis tecta, and Impatiens bicolor, are all endemic to the Himalayan region and vulnerable (Ali 2011; WWF-P 2004). The reasons for the occurrence of these plants only in old-growth forest may be manifold, but one is that they are quite likely adapted to shady conditions. Moreover, regrowth forest and forest degraded by logging might lack the ability to provide a proper environment for the reappearance of these species due to past anthropogenic factors. Other species, such as Paeonia emodi and Podophyllum emodi, occurred only in old-growth and regrowth forests. Although distributed throughout the Himalayas, these species have been reported as highly vulnerable in the study area by WWFPakistan. Comparably shadier conditions than that of forest degraded by logging and about four decades of limited human interference may 
explain the reappearance of such species under regrowth forest. Some species were only found in old-growth forest and forest degraded by logging, such as Gentiana kurroo. Their presence in forest degraded by logging rather than in regrowth forest might be due to the closer proximity to old-growth forest.

In our study, low tree canopy cover appeared to favor species such as Galium aparine, which are more commonly adapted to sunny conditions. The density of these species under regrowth forest and forest degraded by logging was higher than under old-growth forest, perhaps reflecting the more open canopies in the former forest-use types. Some of these species only occurred in forest degraded by logging and regrowth forest, such as Chrysanthemum leucanthemum. Medicinal plant species were also observed to be indifferent to canopy cover, such as Achillea millefolium and Agrimonia eupatoria. These species appear to tolerate partially shady conditions (Fern 1997), although other variables may be relevant as well.

The medicinal plant species recorded in this study are valuable in terms of their traditional usage as medicines at the local level. Moreover, about one-third represent direct economic resources, as indicated by market prices equal to or greater than $0.2 \mathrm{USD} \mathrm{kg}^{-1}$. Species such as Aconitum heterophyllum, Valeriana jatamansi, and Viola canescens, which occurred in higher abundance and frequency in old-growth forest, are traded along an established chain to the city markets and beyond. Demand for such medicinal plants in Pakistan is increasing at present $15 \%$ annually (Shinwari 2010). For example, the total annual consumption of Aconitum heterophyllum increased sharply from $740 \mathrm{~kg}$ in the $1980 \mathrm{~s}$ (Williams and Ahmad 1999) to around ten tons in 2003, or roughly a thirteen-fold increase over twenty years. In the ANP, the extraction of $A$. heterophyllum has increased from $64 \mathrm{~kg}$ in 2003 (Ibrar 2003) to $500 \mathrm{~kg}$ in 2007, or an eight-fold increase in four years. The absence of such species in regrowth forest and forest degraded by logging may well encourage increased harvest in oldgrowth forest.

In conclusion, old-growth forest in the Pakistani Himalaya sustains a highly diverse medicinal flora and plays an important role as refuge for vulnerable endemics. Forest degraded by logging has the lowest diversity of medicinal plants and, to a large extent, harbors more ubiquitous medicinal species. If regrowth is allowed in these degraded areas, this may foster the reappearance of certain medicinal species valuable to local livelihoods and thereby promote local acceptance of forest expansion and medicinal plant conservation in the region.

\section{Acknowledgments}

This work was supported by the Kohat University of Science and Technology (KUST) under the higher education commission of Pakistan's (HEC) Human Resource Development program (HRD) by providing a grant to Muhammad Adnan; the authors are very thankful to the authorities of KUST and HEC for providing this financial support. The authors are also thankful to the World Wide Fund for Nature Pakistan (Peshawar region) team for their kind assistance during data collection. Lastly, thanks to the editor and reviewers of this journal for their valuable suggestions on this article during the review process.

\section{Open Access}

This article is distributed under the terms of the Creative Commons Attribution License which permits any use, distribution, and reproduction in any medium, provided the original author(s) and the source are credited.

\section{Literature Cited}

Adnan, M. and D. Hölscher. 2011. Medicinal plants in old-growth, degraded and regrowth forests of NW Pakistan. Forest Ecology and Management 261:2105-2114.

Aguilar-Støen, M. and S. R. Moe. 2007. Medicinal plant conservation and management: Distribution of wild and cultivated species in eight countries. Biodiversity and Conservation 6:1973-1981.

Ahmad, H. 2003. Capacity building for cultivation and sustainable harvesting of medicinal and aromatic plants. Pages 31-36 in H. Ahmad and A. A. Khan, eds., Conservation and sustainable uses of medical and aromatic plants of Pakistan. Ethnobotany Project, World Wide Fund for Nature Pakistan (WWF-P). Islamabad, Pakistan.

Ali, S. I. 2011. Flora of Pakistan. http://www.efloras. org/flora_page.aspx?flora_id=5 (7 May 2011).

Arnold, J. E. M. and M. R. Pérez. 2001. Can non-timber forest products match tropical forest conservation and development objectives? Ecological Economics 39:437-447. 
Aumeeruddy, T. Y., Z. K. Shinwari, A. Ayaz, and A. A. Khan. 2004. Ethnobotany and management of fodder and fuel wood at Ayubia National Park, Northwest Frontier Province, Pakistan (People and Plants Working Paper). International Plants Conservation Unit, WWF-UK. www.peopleandplants.org/storage/ working-papers/wp13.pdf (20 July 2011).

Balandier, P., C. Collet, J. Miller, P. Reynolds, and S. Zedaker. 2006. Designing forest vegetation management strategies based on the mechanisms and dynamics of crop tree competition by neighbouring vegetation. Forestry 79:3-27.

Barbier, S., F. Gosselin, and P. Balandier. 2008. Influence of tree species on understory vegetation diversity and mechanisms involved-A critical review for temperate and boreal forests. Forest Ecology and Management 254:1-15.

Beigh, S. Y., I. A. Nawchoo, and M. Iqbal. 2006. Cultivation and conservation of Aconitum heterophyllum: A critically endangered medicinal herb of the northwest Himalayas. Journal of Herbs, Spices and Medicinal Plants 11 (4):47-56.

Bhuyan, P., M. L. Khan, and R. S. Tripathi. 2003. Tree diversity and population structure in undisturbed and human-impacted stands of tropical wet evergreen forest in Arunachal Pradesh, Eastern Himalayas, India. Biodiversity and Conservation 12:1753-1773.

Carnevale, N. J. and F. Montagnini. 2002. Facilitating regeneration of secondary forests with the use of mixed and pure plantations of indigenous tree species. Forest Ecology and Management 163:217-227.

Chao, A., R. L. Chazdon, R. K. Colwell, and T. J. Shen. 2005. A new statistical approach for assessing similarity of species composition with incidence and abundance data. Ecology Letters 8:148-159.

Curtis, J. T. and R. P. McIntosh. 1951. An upland forest continuum in the prairie-forest border region of Wisconsin. Ecology 32:476-496.

D'Amato, A. W., D. A. Orwig, and D. R. Foster. 2009. Understory vegetation in old-growth and second-growth Tsuga canadensis forests in western Massachusetts. Forest Ecology and Management 257:1043-1052.

Dufrêne, M. and P. Legendre. 1997. Species assemblages and indicator species: The need for a flexible asymmetrical approach. Ecological Monographs 67:345-366.
FAO (Food and Agriculture Organization). 2005. State of the world's forests. Rome: Food and Agriculture Organization. http://www.fao.org/ docrep/007/y5574e/y5574e00.htm (28 June 2011).

Farooque, M. 2002. Management plan of Ayubia National Park 2002-2007. National Resource Conservation Project, Galiat, Abbottabad, Pakistan.

Fern, K. 1997. Plants for a future: Edible, medicinal and useful plants for a healthier world. U.K.: Permanent Publication. http:// www.pfaf.org/user/default.aspx (10 April 2011).

Gillani, S. A., Y. Fujii, Z. K. Shinwari, M. Adnan, A. Kikuchi, and K. N. Watanabe. 2010. Phytotoxic studies of medicinal plant species of Pakistan. Pakistan Journal of Botany 42:987-996.

Gilliam, F. S. 2007. The ecological significance of the herbaceous layer in temperate forest ecosystems. Bioscience 57:845-858.

Hamilton, A. C. 2004. Medicinal plants, conservation and livelihoods. Biodiversity and Conservation 13:1477-1517.

Harrelson, S. M. and G. R. Matlack. 2006. Influence of stand age and physical environment on the herb composition of secondgrowth forest, Strouds Run, Ohio, USA. Journal of Biogeography 33:1139-1149.

Hussain, K. 2003. Impact of grazing on infiltration capacity of soil [report on Ayubia National Park]. World Wide Fund for Nature Pakistan, Peshawar.

Ibrar, M. 2003. Conservation of indigenous medicinal plants and their traditional knowledge found in moist temperate Himalayas Pakistan. Ph.D. thesis, Quaid-i-Azam University, Islamabad, Pakistan.

Index Kewensis 2.0. 1997. On compact disc version 2.0 for the IBM PC. Oxford University Press, Oxford.

Islam, K. R., M. R. Ahmed, M. K. Bhuiyan, and A. Badruddin. 2001. Deforestation effects on vegetative regeneration and soil quality in tropical semi-evergreen degraded and protected forests of Bangladesh. Land Degradation and Development 12:45-56.

ITC (Faculty of Geo-Information Science and Earth Observation). 2007. ILWIS (The Integrated Land and Water Information System). http://www.itc.nl/ilwis (10 October 2007). 
Kala, C. P. 2004. Indigenous uses, population density, and conservation of threatened medicinal plants in protected areas of the Indian Himalayas. Conservation Biology 19:368-378.

Keersmaeker, L. D., K. Vandekerkhove, A. Verstraeten, L. Baeten, P. Verschelde, A. Thomaes, M. Hermy, and K. Verheyen. 2011. Clear-felling effects on colonization rates of shade-tolerant forest herbs into a post-agricultural forest adjacent to ancient forest. Applied Vegetation Science 14:75-83.

Kumar, A. and J. Ram. 2005. Anthropogenic disturbances and plant biodiversity in forests of Uttaranchal, central Himalaya. Biodiversity and Conservation 14:309-331.

Larsen, H. O., C. S. Olsen, and T. E. Boon. 2000. The non-timber forest policy process in Nepal: Actors, objectives and power. Forest Policy and Economics 1:267-281.

Liira, J., T. Sepp, and O. Parrest. 2007. The forest structure and ecosystem quality in conditions of anthropogenic disturbance along productivity gradient. Forest Ecology and Management 250:34-46.

Lubna, H. 2001. Analyzing institutional set-up of forest management in Pakistan [Munich personal RePEc archive MPRA paper no. 7343]. Pakistan Institute of Development Economics. http:// mpra.ub.uni-muenchen.de/7343/ (5 May 2011).

Magurran, A. 2004. Measuring biological diversity. Blackwell, London.

McCune, B. and M. J. Mefford. 1999. PC-ORD, Multivariate analysis of ecological data, Version 5.01. MjM Software, Gleneden Beach, Oregon.

Mishra, B. P., O. P. Tripathi, R. S. Tripathi, and H. N. Pandey. 2004. Effect of anthropogenic disturbance on plant diversity and community structure of a sacred grove in Meghalaya, northeast India. Biodiversity and Conservation 13:421-436.

Nath, P., A. Arunachalam, M. Khan, K. Arunachalam, and A. Barbhuiya. 2005. Vegetation analysis and tree population structure of tropical wet evergreen forests in and around Namdapha National Park, northeast India. Biodiversity and Conservation 14:2109-2136.

Negi, V. S., R. K. Maikhuri, and L. S. Rawat. 2011. Non-timber forest products (NTFPs): A viable option for biodiversity conservation and livelihood enhancement in central Himalaya. Biodiversity and Conservation 20:545-559.

Olsen, C. S. 2005. Valuation of commercial central Himalayan medicinal plants. Ambio 34:607-610.
Parrotta, J. A., J. W. Turnbull, and N. Jones. 1997. Catalyzing native forest regeneration on degraded tropical lands. Forest Ecology and Management 99:1-7.

Putz, F. E. and K. H. Redford. 2010. The importance of defining "Forest": Tropical forest degradation, deforestation, long-term phase shifts, and future transitions. Biotropica 42:10-20.

Rabia, A. and A. A. Khan. 2004. Medicinal plants of Ayubia National Park: Prospective and constraints. Pages 153-161 in Z. K. Shinwari and T. Watanabe, eds., International Symposium on Medicinal Plants: Linkages beyond national boundaries, Proceedings 1, Vol. 1. Pakistan Agriculture and Research Council, Islamabad.

Rodriguez, A. 2010. Pakistan flood crisis blamed partly on deforestation. Los Angeles Times October 13, 2010. http://articles.latimes.com/ 2010/oct/13/world/la-fg-pakistan-logging20101013 (31 August 2011).

Samant, S. S. and U. Dhar. 1997. Diversity, endemism and economic potential of wild edible plants of Indian Himalaya. International Journal of Sustainable Development and World Ecology 4:179-191.

Schickhoff, U. 1995. Himalayan forest-cover changes in historical perspective: A case study in the Kaghan valley, northern Pakistan. Mountain Research and Development 15:3-18.

Shafiq, C. M. 2003. Some aspect of bio-ecology of Ayubia National Park Northwest Frontier Province, Pakistan. Department of Zoology, University of Karachi. http://eprints.hec. gov.pk/1294/1/1008.html.htm (6 June 2011).

Shankar, U., S. D. Lama, and K. S. Bawa. 1998. Ecosystem reconstruction through "taungya" plantations following commercial logging of a dry, mixed deciduous forest in Darjeeling Himalaya. Forest Ecology and Management 102:131-142.

Shanley, P. and L. Luz. 2003. The impacts of forest degradation on medicinal plant use and implications for health care in eastern Amazonia. Bioscience 53:573-584.

Sharma, G., B. P. Nyutiyal, and A. R. Nautiyal. 2009. Seedling emergence and survival in Cinnamomum tamala under varying microhabitat conditions: Conservation implications. Tropical Ecology 50:201-209.

Sher, H. and Z. D. Khan. 2006. Resource utilization for economic development and folk medicine among the tribal people: Observation 
from northern part of Pakistan. Pakistan Journal of Plant Sciences 12:149-162.

Shinwari, Z. K. 2010. Medicinal plants research in Pakistan. Journal of Medicinal Plants Research 4:161-176.

SPSS Inc. 2007. SPSS version 16.0 for Windows. Chicago.

Sundriyal, R. C. and E. Sharma. 1996. Anthropogenic pressure on tree structure and biomass in the temperate forest of Mamlay watershed in Sikkim. Forest Ecology and Management 81:113-134.

Ticktin, T., H. Fraiola, and N. Whitehead. 2007. Non-timber forest product harvesting in aliendominated forests: Effects of frond-harvest and rainfall on the demography of two native Hawaiian ferns. Biodiversity and Conservation 16:1633-1651.

Uniyal, P., P. Pokhriyal, S. Dasgupta, D. Bhatt, and N. P. Todaria. 2010. Plant diversity in two forest types along the disturbance gradient in Dewalgarh watershed, Garhwal Himalaya. Current Science 98:7-10.

Voeks, R. A. 1996. Tropical forest healers and habitat preference. Economic Botany 50 (3):354-373.
2004. Disturbance pharmacopoeias: Medicine and myth from the humid tropics. Annals, Association of American Geographers 94(4):868-888.

Williams, J. T. and Z. Ahmad. 1999. Priorities for medicinal plants research and development in Pakistan. Medicinal and Aromatic Plants Program in Asia (MAPPA), New Delhi, India. http://idl-bnc.idrc.ca/dspace/bitstream/10625/ 22721/1/110243.pdf (17 August 2011).

WWF-P (World Wide Fund for NaturePakistan). 2004. People and plants-Pakistan: Capacity building in ethnobotany applied to conservation and sustainable use of plant resources (Annual Progress Report 19992004). WWF-P Peshawar office, Peshawar.

Wyatt, J. L. and M. R. Silman. 2010. Centuries-old logging legacy on spatial and temporal patterns in understory herb communities. Forest Ecology and Management 260:116-124.

\section{Electronic supplementary material}

Below is the link to the electronic supplementary material.ESM 1 (DOC $131 \mathrm{~kb}$ ) 